\title{
Predictive value and changes of inducible nitric oxide synthase expression in patients with rectal cancer under the influence of antitumor therapy
}

\author{
V. V. Holotiuk, A. Ye. Kryzhanivska, I. Ya. Sadovyi, B. B. Tataryn \\ SHEI “Ivano-Frankivsk National Medical University”, Ukraine
}

The aim of investigation - to establish the features of iNOS expression in the rectum wall under the influence of various neoadjuvant therapy options in patients with rectal cancer $(\mathrm{RC})$ and to find out its predictive significance.

Materials and methods. In 88 patients with stage II-III rectal adenocarcinoma we established iNOS expression in the tumor before and after neoadjuvant radiotherapy (NRT), therapeutic pathomorphosis grade and density of immune cell infiltrates. Patients were divided into 3 groups: 1 - patients after the course of NRT on the tumor site; 2 - patients who underwent chemoradiomodification of the NRT with drug tegafur; 3 - patients who underwent chemoradiomodification of the NRT with tegafur and L-arginine.

Results. In the tumors of rectal cancer the level of iNOS expression by 4.5 times exceeded that in the intact rectum wall $(P<0.001)$, correlated with metastatic lesion of the regional lymph nodes $(r=0.55 ; P=0.026)$ and depended on the type of growth of RC. The level of iNOS expression in the tumor prior to treatment in Group 3 patients, in which the high efficacy of NRT was reported, was $54.61 \pm 3.55$ versus $35.10 \pm 2.28 \mathrm{CU}$ in the rest of the patients $(P=0.01)$. After NRT, most Groups 1-2 patients reduced the iNOS expression in the RC tissue - on the average to $37.30 \pm 4.13 \mathrm{CU}$, more in the residual parenchyma as compared to the tumor stroma, while Group 1 patients showed the lowest total immunosensitivity intensity of iNOS - $24.34 \pm 3.10 \mathrm{CU}$, and Group 3 patients - the highest - $45.35 \pm 5.84 \mathrm{CU}$.

Conclusions. After the use of NRT, iNOS expression in the residual parenchyma of the RC decreased, but in the stroma the marker expression remained unchanged or there was an increase in the marker expression, which was most inherent to therapeutic pathomorphosis grades III-IV. iNOS expression in the RC stroma was highest in patients after NRT with radiomodification using tegafur and L-arginine and positively correlated with the density of immune cell infiltrates in the tumor. Evaluation of the preoperative level of iNOS in patients with RC can serve as a predictive test of advisability of NRT used on the background of radiomodification with L-arginine.

Предиктивне значення та зміни експресії індуцибельної синтази оксиду азоту у хворих на рак прямої кишки під впливом протипухлинної терапії

\section{В. В. Голотюк, А. Є. Крижанівська, І. Я. Садовий, Б. Б. Татарин}

Мета роботи - визначити особливості змін експресії iNOS у стінці прямої кишки під впливом застосування різних варіантів неоад'ювантної терапії у хворих на рак прямої кишки (РПК), з'ясувати її предиктивне значення.

Матеріали та методи. У 88 хворих на аденокарциному прямої кишки II-III стадій імунофрлуоресцентно визначили експресію iNOS у пухлині до та після неоад'ювантної променевої терапії (HПT), ступінь лікувального патоморфозу та щільність імуноклітинних інфільтратів. Пацієнтів поділили на 3 групи: I - хворі після курсу НПТ на ділянку пухлини; II - пацієнти, яким виконали радіомодиффікацію НПТ препаратом тегафуру; III - хворі, які отримали радіомодифікацію HПТ препаратами тегафуру та L-аргініну.

Результати. У пухлинах РПК рівень експресії iNOS в 4,5 раза перевищував таку в інтактній стінці прямої кишки $(p<0,001)$, корелював з метастатичним ураженням реґіонарних лімфовузлів $(r=0,55 ; p=0,023)$ і залежав від типу росту РПК. Рівень експресії iNOS у пухлині до лікування у хворих III групи, в яких констатована висока ефективність НПТ, становив $54,61 \pm 3,55$ проти $35,10 \pm 2,28$ ум. од. у решти хворих ( $p=0,01)$. Після НПТ у більшості хворих I-II груп визначили зниження експресії iNOS у тканині РПК у середньому до $37,30 \pm 4,13$ ум. од., більше в резидуальній паренхімі порівняно зі стромою пухлини. У хворих I групи зареєстрували найменшу сумарну інтенсивність імуносигналу iNOS $(24,34 \pm 3,10$ ум. од.), а у хворих III групи - найвищу $(45,35 \pm 5,84$ ум. од.)

Висновки. Після застосування HПT експресія INOS у резидуальній раковій паренхімі РПК знижується, але у стромі залишається без змін чи спостерігається зростання експресії маркера, яке є найбільш характерним для III-IV ступенів патоморфозу. Експресія iNOS у стромі РПК найвища у хворих після HПT із радіомодифікацією тегафуром, L-аргініном і позитивно корелює зі щільністю імуноклітинних інфільтратів у пухлині. Визначення доопераційного рівня iNOS у хворих на РПК може бути предиктивним тестом доцільності застосування HПТ із потенціюванням L-аргініном.

\section{Предиктивное значение и изменения экспрессии индуцибельной синтазы оксида азота у больных раком прямой кишки под влиянием противоопухолевой терапии}

\section{В. В. Голотюк, А. Е. Крыжанивская, И. Я. Садовый, Б. Б. Татарин}

Цель работы - определить особенности изменений экспрессии iNOS в стенке прямой кишки под влиянием применения различных вариантов неоадъювантной терапии у больных раком прямой кишки (РПК) и выяснить ее предиктивное значение.
Key words: inducible nitric oxide synthase, rectal cancer, pathology, chemotherapy, radiotherapy, L-arginine, tegafur.

Pathologia 2018; 15 (2), 199-203 DOI: 10.14739/2310-1237 2018.2.141349

E-mail: golotiuk1@ukr.net

Киючові слова: індуцибельна синтаза оксиду азоту, рак прямої кишки, мікувальний патоморфоз, хіміопроменева терапія, L-аргінін, тегафур.

Патологія. - 2018. T. 15, № 2(43). -

C. $199-203$ 
Патология. - 2018. T. 15, № 2(43). C. 199-203

Материалы и методы. У 88 больных с аденокарциномой прямой кишки II-III стадий иммунофрлуресцентно определяли экспрессию iNOS в опухоли до и после неоадъювантной лучевой терапии (НЛТ), степень лечебного патоморфоза и плотность иммуноклеточных инфильтратов. Пациентов поделили на 3 группы: I - больные после курса НЛТ на зону опухоли; II - пациенты, которые получили радиомодификацию НЛТ препаратом тегафура; III - больные, которым провели радиомодификацию HЛT препаратами тегафура и L-аргинина.

Результаты. В опухолях РПК уровень экспрессии iNOS в 4,5 раза превышал таковой в интактной стенке прямой кишки ( $\mathrm{p}$ 0,001), коррелировал с метастатическим поражением регионарных лимфоузлов $(r=0,55 ; p=0,026)$ и зависел от типа роста РПК. Уровень экспрессии iNOS в опухоли до лечения у больных III группы, у которых констатирована высокая эффективность НЛТ, составил $54,61 \pm 3,55$ против $35,10 \pm 2,28$ у. е. у остальных больных $(p=0,01)$. После НЛТ у большинства больных I-II групп отмечали снижение экспрессии INOS в ткани PПК - в среднем до 37,30 $\pm 4,13$ у. е., в большей степени в резидуальной паренхиме по сравнению с стромой опухоли. При этом у больных группы зарегистрировали наименьшую суммарную интенсивность иммуносигнала iNOS $(24,34 \pm 3,10$ у. е.), а у больных III группы - наивысшую (45,35 $\pm 5,84$ у. е.).

Выводы. После применения HЛT экспрессия INOS в резидуальной раковой паренхиме РПК снижается, однако в строме остается без изменений или отмечают рост экспрессии маркера, что наиболее характерно для случаев III-IV степени патоморфоза. Экспрессия iNOS в строме РПК самая высокая у больных после НЛТ с применением тегафура и L-аргинина и положительно коррелирует с плотностью иммуноклеточных инфильтратов в опухоли. Определение дооперационного уровня INOS у больных РПК может служить предиктивным тестом целесообразности применения HЛТ с потенцированием L-аргинином.

Redox-dependent NO molecules play an important role in regulation of the proliferative processes of cancer cells due to metabolic, damaging and signaling ways $[1,2]$. Nowadays, it is known that nitric oxide (NO) in relation to malignant neoplasms can exhibit dual activity - both to stimulate tumour growth, and to cause antitumor effect, while the direction of action of $\mathrm{NO}$ in the tumours primarily and the most depends on its concentration [3,4]. NO can also have a great effect on other aspects of tumour biology, including angiogenesis and metastasizing $[1,3]$. It has been found out that inducible nitric oxide synthase (iNOS) is the main source of NO synthesis in tumours. Possessing the ability to synthesize large volumes of NO over a long period of time, iNOS functions as a rule in response to cell activation by cytokines or bacterial antigens [5]. In a short time, it has the ability to increase the concentration of NO fortyfold or more, depending on the intensity of the stimulating factor [2]. Nitric oxide on exposure to iNOS is formed by a two-stage hydroxylation reaction of the citrulline cycle from L-arginine, resulting in stoichiometrically formed nitric oxide in the free radical form (NO) and L-citrulline [6]. Nitrogen oxide produced by iNOS in large amounts is toxic. It enables NO to perform in the body both protective functions (neutralize tumour and bacterial cells), and to participate in pathological processes, inducing apoptosis [7].

Considering the importance of NO in the pathogenesis of malignancy and the mechanisms of antitumor therapeutic effects, researchers in various countries investigate the characteristics of the biological system of NO synthesis in colorectal cancer tumors, which serves as a basis for the development of new therapeutic approaches and personalization of patients treatment. However, nowadays, literature data on the characteristics of iNOS expression in colorectal cancer tumors, its prognostic and predictive value are ambiguous and require further study [8-10].

\section{The aim}

To establish features of iNOS expression in the rectum wall under the influence of various neoadjuvant therapy options in patients with rectal cancer (RC) and to find out its predictive significance.

\section{Materials and methods}

The results of the examination of 88 patients with $R C$ who were treated in the Precarpathian clinical oncological center have been analyzed. 50 patients were diagnosed at stage II $\left(\mathrm{T}_{3-4} \mathrm{~N}_{0} \mathrm{M}_{0}\right)$ and 38 - stage III $\left(\mathrm{T}_{2-4} \mathrm{~N}_{1-2} \mathrm{M}_{0}\right)$ of the disease. The mean age of the patients was $61.30 \pm 1.29$ years (from 45 to 74 years), there were 47 (53\%) male patients, and $41(47 \%)$ female patients. All patients had a verified stage II-III adenocarcinoma. Diagnosis, stage of the disease and the presence of metastases were established in accordance with the requirements of evidence-based medicine (by performing clinical and instrumental examinations and pathomorphologically). The research was performed in accordance with the principles of conducting biomedical research involving human subjects set forth in the World Medical Association Declaration of Helsinki.

Depending on the treatment received, the patients were divided into 3 groups:

Group 1 included 30 patients who received the course of neoadjuvant radiation therapy (NRT) on the tumor site to a total focal dose of 38-40 Gy (single focal dose 2.0-2.5 Gy, 5 sessions per week) without the use of radiomodifiers with surgical after-treatment 4-6 weeks later.

Group 2 included 29 patients who received a similar course of NRT with the chemoradiomodification with tegafur at a dose of $800 \mathrm{mg}$ twice per os daily to patients weighing up to $70 \mathrm{~kg}$ or $1200 \mathrm{mg}$ three times daily to patients with a weight of more than $70 \mathrm{~kg}$ during the whole course of the NRT.

Group 3 included 29 patients who underwent the same course of NRT, and besides tegafur they received L-arginine infusions in a dose of $100 \mathrm{ml}$ per 1 hour before the radiotherapy session $(4.2 \%$ solution of L-arginine hydrochloride), which, being a substrate for iNOS, is a precursor of NO formation in the tumour tissue.

The object of our study were fragments of intact gut $3 \mathrm{~cm}$ from the edge of the tumor and RC samples 
DAPI

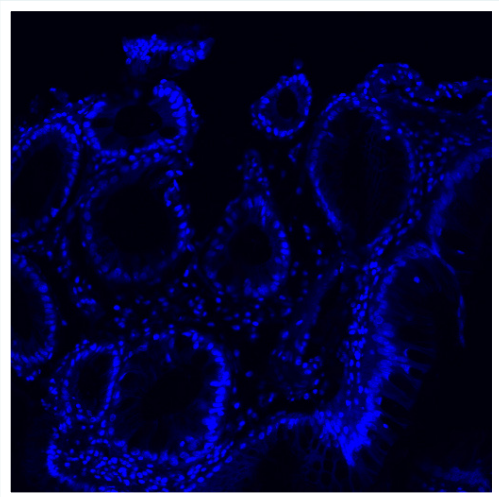

iNOS

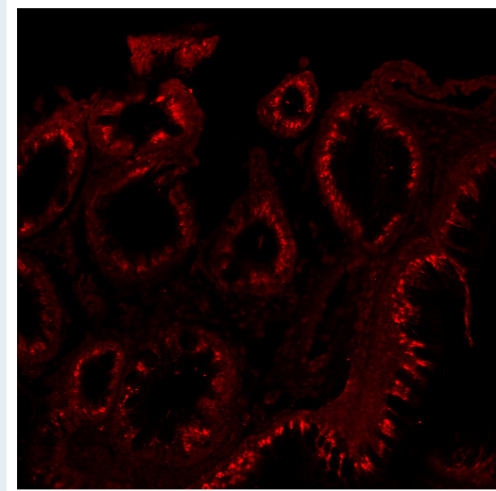

Combined image

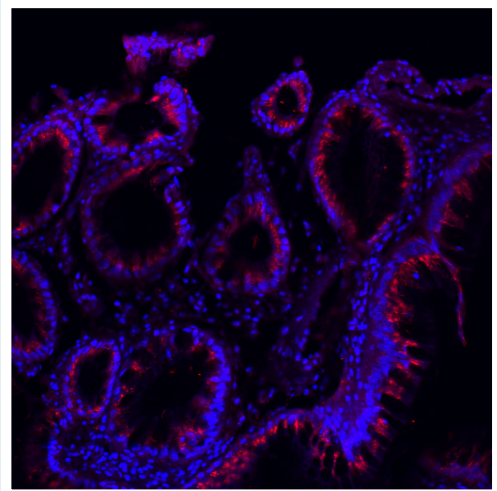

Fig. 1. iNOS expression in rectal cancer patients before treatment: high level of iNOS expression in the cytoplasm of atypical epithelial complexes of rectal cancer (Immunofluorescence microscopy). Magn. $\times 200$.

DAPI: nuclei visualization, iNOS: immunosignal of iNOS in the tumor tissue.

obtained during the biopsy before the treatment onset and from the surgical material. Single tissue plate was dissected from three tumor zones (peripheral, interstitial, and central) for histopathologic investigation of RC surgical material. Histologic sections on the upper, middle and lower levels of paraffin blocks were made, thus nine sections from each operated patient were analyzed. Serial paraffin sections 4-5 microns thick were stained with hematoxylin and eosin. Microscopy and photographing were performed on a microscope of Leica DME (Germany) at $\times 40, \times 100, \times 200$ and $\times 400$ magnifications. Therapeutic pathomorphosis grade was estimated according to G. O. Lavnikova, the density of immune cell infiltrates morphometrically.

Localization and endogenous expression levels of iNOS were assessed by immunofluorescence imaging techniques which was performed in sections of biopsy and $\mathrm{RC}$ surgical material $4 \mu \mathrm{m}$ thick. Anti-NOS2 (Santa Cruz, CA, USA, titer 1: 200) was used as primary antibodies. Alexa Fluor 546 (Invitrogen, USA, titer 1: 500) was used as secondary fluorescein-containing antibodies. Cell nuclei were visualized using 4.6-diamino-2-phenylindole (DAPI, $1.5 \mathrm{mg} / \mathrm{ml}$ ), which was added to the phosphate buffer on the last washing. Immune positive tissues were investigated using a Zeiss LSM 510 laser confocal microscope with a 32-channel automatic polychromatic META detector (GaAsP) and an oil-immersion lens 40X/1.4NA. Five randomly chosen zones were photographed at each section. Analysis of the detected immune signal intensity was performed using the ImageJ 1.48 software. Variational and statistical analysis was performed using the application Statistica v.6.1 (s/n: RGXR412D674002FWC7). The normal distribution was evaluated according to the Shapiro-Wilk test. Digital information of all clinical investigations was processed by variance statistical method calculating the mean value $(M)$ and its error $(m)$. The significance of difference between two means was calculated by Student's t-test (t). Correlation analysis with calculation of Pearson's correlation ( $r$ ) was used to establish the relationship between the studied indices. The difference between the values was considered reliable if significance value was $95 \%(P<0.05)$.

\section{Results of research}

The total level of the iNOS immune signal in the mucous membrane of the rectum in patients with rectal cancer (RC) before treatment was low, amounting to an average of $10.98 \pm 1.07$ conventional unit (CU). Expression of the marker was found mainly in the pericapillar stromal components of lamina propria of the mucous membrane in the areas of immunocytes aggregation. Immunosignal was recorded in the form of single foci of high intensity, often diffuse, and less frequently in the form of macrogranular nature. In the cytoplasm of epithelial cells, both luminal and basal part of the intestinal crypts, isolated foci of iNOS expression of moderate to low intensity were detected. They were irregular and characterized by a diffuse distribution of the marker with concentration predominantly in the zone of the basal cell pole and the juxtanuclear zone.

In RC tumors, the total iNOS expression was 4.5 times higher than in the adjacent rectal mucosa $(P<0.001)$ and averaged $49.21 \pm 3.52 \mathrm{CU}$. At the same time, iNOS immunosignal was detected both in the cells of cancerous glands and in the tumors stroma. Quantitative analysis showed that the total intensity of iNOS expression in stromal cells of RC exceeded that in tumor parenchyma cells by $24 \%(52.54 \pm 4.29$ and $42.47 \pm 3.18$ CU respectively, $\mathrm{P}=0.037$ ). The marker in the RC tissue was unevenly distributed, in particular, within the stroma the immunosignal of iNOS was visualized mainly in the areas of immune-cell infiltrates. At the same time, full visual fields, where only the background level of the marker was detected in the cancerous cells, alternated with sites of high iNOS immunosensitivity in most cells of the cancerous epithelium parenchyma. In such cases, the iNOS expression was equal across the perimeter of atypical cancerous glands, and in the epitheliocytes themselves - homogeneous, high and medium intensities with predominance in the cytoplasm of parabasal cell parts (Fig. 1).

The level of iNOS expression in tumor tissue in patients with RC did not correlate with age, sex, localization, tumor size and differentiation grade, but at the same time, 


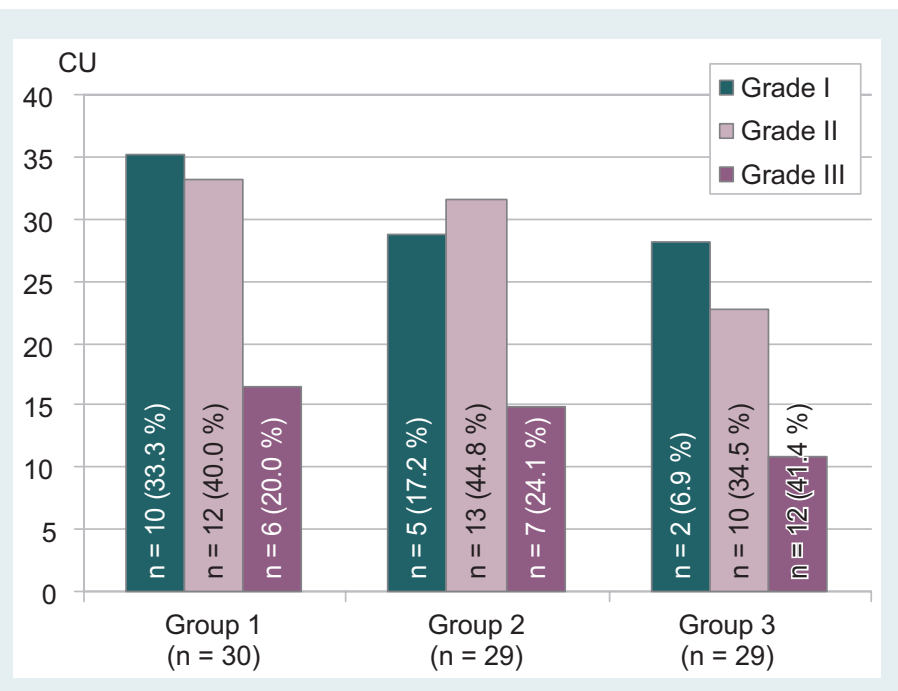

Fig. 2. Indicators of iNOS expression within residual cancer parenchyma in patients with RC of groups 1-3 depending on the post-radiation pathomorphosis grade.

$\%$ : portion of I-III pathomorphosis grades for each group of patients is indicated; patients with pathomorphosis grade IV are not reflected because of residual cancer parenchyma absence, so the sum of the number of patients in subgroups, depending on the pathomorphosis degree is less than the total number of patients in the corresponding groups.

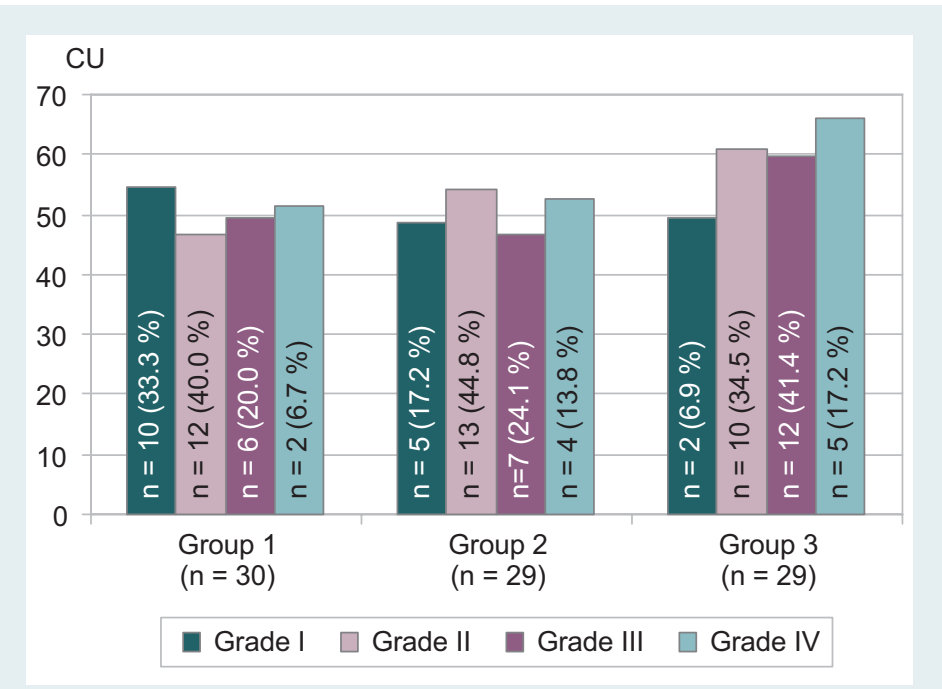

Fig. 3. Indicators of iNOS expression within the tumor stroma in patients with RC of groups 1-3 depending on the post-radiation pathomorphosis grade.

\%: portion of I-IV pathomorphosis grades for each group of patients is indicated.

we found a positive relationship between iNOS expression and the number of registered lymph nodes with metastases. Thus, in the subgroup of patients with criterion $\mathrm{N}_{1-2}$, the average iNOS expression was $58.63 \pm 6.11 \mathrm{CU}$, whereas in the absence of metastases in the lymph nodes $-41.30 \pm 5.05 \mathrm{CU}(r=0.55 ; P=0.026)$. Also, a statistically significant relationship was recorded with respect to the type of growth of $\mathrm{RC}$ : in the exophytic tumors the iNOS index was $43.13 \pm 5.27 \mathrm{CU}$, in cases of tumors with endophytic and mixed types of growth $61.16 \pm 7.19(P=0.021)$.

In order to investigate the effect of iNOS expression level in the tumor on the direct effect of NRT, the relation- ship between marker expression and the level of treatment post-radiation pathomorphosis was studied. At the same time, the efficacy of the therapy was taken low for pathomorphosis grades I-II and considered high in the cases of pathomorphosis III-IV grades. It was found that the level of iNOS expression in the tumor before treatment in groups 1-2 patients, for which in the future high efficiency of NRT was registered, slightly exceeded that in patients with a low sensitivity to the received treatment: the rate was $50.24 \pm 4.09$ and $46.67 \pm 5.47 \mathrm{CU}$ respectively, while the difference in average values was unreliable $(P>0.05)$. Patients in the $3^{\text {rd }}$ group experienced a similar trend, but the difference in rates was more significant and reliable, accounting for $54.61 \pm 3.55$ and $35.10 \pm 2.28$ respectively $(P=0.01)$. This suggests that patients with high iNOS levels in the tumor are more susceptible to NRT in the background of radiomodification using the precursor of biological synthesis of NO, which confirms the pathogenetic feasibility of its usage for this purpose.

After the use of NRT, in the majority of groups 1-3 patients, decrease in the iNOS expression in the RC tissue was observed - on average up to $37.30 \pm 4.13 \mathrm{CU}$. Negative dynamics was significantly more pronounced in the areas of residual cancer parenchyma as compared with the stroma, where the reduction in iNOS expression after the performed treatment was negligible and unreliable by contrast to the baseline (Fig. 2, 3).

Moreover, in some cases, even an increase in the total intensity of the iNOS immune signal in the tumor stroma was noted. This phenomenon was the most characteristic for group 3 patients, where iNOS expression in stromal elements exceeded the parameters of groups 1 and 2 patients and increased in parallel with the grade of therapeutic pathomorphosis. It was the largest in cases of grade IV pathomorphosis on the background of the complete lack of viable cancer parenchyma (Fig. 3). Obviously, the latter is associated with a large area of reactive cell infiltration of functional-active iNOS-expressing macrophages and leukocytes, which take part in the postradiational reorganization of irradiated tissue and regulation of desmoplastic reactions.

The same cause, in our opinion, is the basis for different mean total iNOS expression in the tumour tissue at this stage of the study taking into account the distribution of patients to experimental groups. In particular, group 1 patients showed the

lowest total iNOS immunosignal intensity $24.34 \pm 3.10 \mathrm{CU}$, group III patients $-38.30 \pm 4.41 \mathrm{CU}$ and group IV patients the highest $-45.35 \pm 5.84 \mathrm{CU}$ (the difference between the mean values of groups 1-2 and groups 1-3 was relevant - correspondingly $P=0.019$ and $P=0.013$ ) (Fig. 4).

Indicated dynamics corresponded to different density of immune cell infiltrates established in the study of the post-radiation pathomorphosis parameters in the histopreparations of RC and correlated in the groups of patients as $1<2<3$.

\section{Discussion}

Macrophages, which are the part of peritumoral inflammatory infiltrates, can provide radiosensibilization 
of the neoplasm due to the secretion of proinflammatory cytokines, therefore increasing secondarily the expression and functional activity of iNOS in tumor cells $[1,4,8]$. Thus, taking into account the data received in our study, it is suggested that the administration of L-arginine hydrochloride to the patients with $R C$ before the irradiation session contributes to increased synthesis of endogenous $\mathrm{NO}$ in the neoplasm as a result of iNOS expressed by neutrophils and activated (M1) macrophages activity, which is known to possess the ability to increase the sensitivity of the tumor to ionizing radiation $[1,2]$.

\section{Conclusions}

1. 4-6 weeks after the completion of NRT iNOS expression in residual parenchyma of the $\mathrm{RC}$ decreases, but in the stroma remains unchanged or there is an increase in the marker expression, which is the most inherent to pathomorphosis grades III-IV.

2. The iNOS expression in the stoma of RC was highest in patients after the NRT on the background of radiomodification with tegafur and L-arginine and positively correlated with the density of immune cells infiltrates in the tumor.

3. Evaluation of the preoperative level of iNOS in the tumor in patients with RC can serve as a diagnostic predictive test of advisability of radio-modification using L-arginine in the course of NRT.

Conflicts of Interest: authors have no conflict of interest to declare. Конфлікт інтересів: віАсутній.

\section{Information about authors:}

Holotiuk V. V., MD, PhD, DSc, Associate Professor, Department of Oncology, Ivano-Frankivsk National Medical University,

Ukraine.

Kryzhanivska A. Ye., MD, PhD, DSc, Head of the Department of Oncology, Ivano-Frankivsk National Medical University, Ukraine. Sadovyi I. Ya., MD, PhD, Assistant, Department of Surgery \#2, Ivano-Frankivsk National Medical University, Ukraine. Tataryn B. B., MD, Assistant, Department of Oncology, IvanoFrankivsk National Medical University, Ukraine.

\section{Відомості про авторів:}

Голотюк В. В., А-р меА. наук, Аоцент каф. онкології, ІваноФранківський національний медичний університет, Україна. Крижанівська А. Є., А-р меА. наук, зав. каф. онкології, ІваноФранківський національний медичний університет, Україна. Садовий І. Я., канд. меА. наук, асистент каф. хірургії № 2, ІваноФранківський національний медичний університет, Україна. Татарин Б. Б., асистент каф. онкології, Івано-Франківський національний медичний університет, Україна.

\section{Сведения об авторах:}

Голотюк В. В., А-р меА. наук, Аоцент каф. онкологии, ИваноФранковский национальный медицинский университет, Украина.

Крыжанивская А. Е., А-р меА. наук, зав. каф. онкологии, Ивано-Франковский национальный меАицинский университет, Украина.

Садовый И. Я., канА. меА. наук, ассистент каф. хирургии № 2 , Ивано-Франковский национальный меАицинский университет, Украина.

Татарин Б. Б., ассистент каф. онкологии, Ивано-Франковский национальный медицинский университет, Украина.

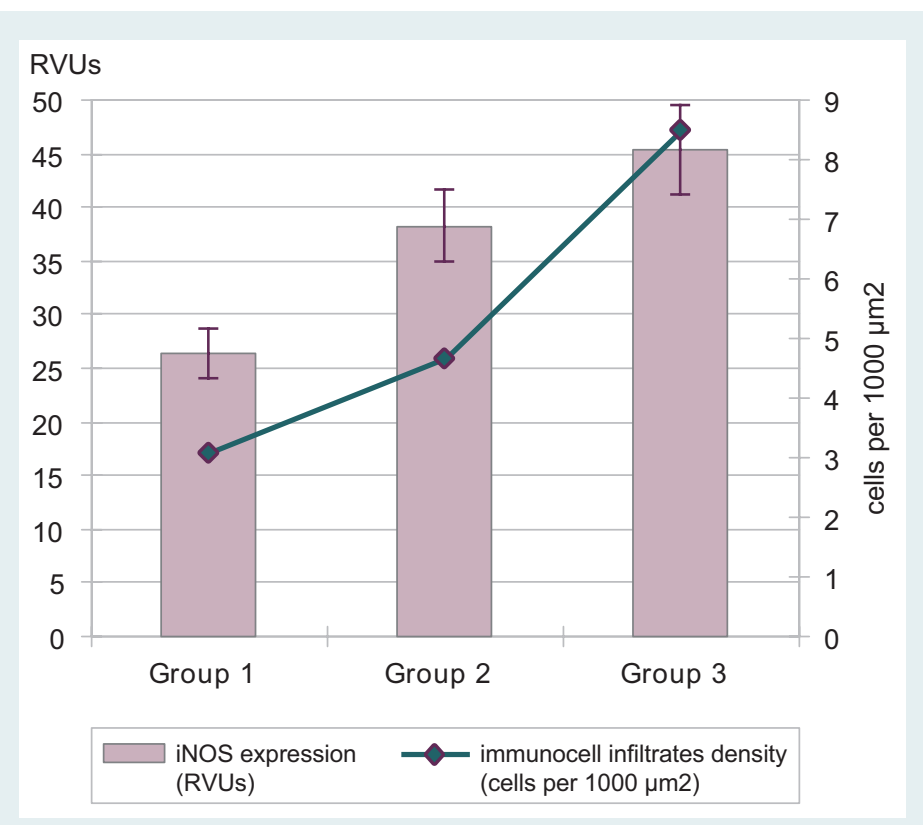

Fig. 4. Correlation of iNOS expression in the tumor and density of immune cell infiltrates in patients with RC.

Надійшла Ао редакції / Received: 07.05.2018

Після Аоопрацювання / Revised: 29.05.2018

Прийнято Ао Аруку / Accepted: 05.06.2018

\section{References}

[1] Bonavida, B. (Ed) (2015). Nitric Oxide and Cancer: Pathogenesis and Therapy. Los Angeles. doi.org/10.1007/978-3-319-13611-0.

[2] Huerta, S., Chilka, S., \& Bonavida, B. (2008). Nitric oxide donors: novel cancer therapeutics (review). Int J Oncol, 33(5), 909-27. doi. org/10.3892/ijo 00000079.

[3] Choudhari, S. K., Chaudhary, M., Bagde, S., Gadbail, A. R., \& Joshi, V. (2013). Nitric oxide and cancer: a review. World J Surg Oncol, 11, 118. doi: 10.1186/1477-7819-11-118.

[4] Wink, D. A., Hines, H. B., Cheng, R. Y., Switzer, C. H., Flores-Santana, W., Vitek, M. P., et al. (2011). Nitric oxide and redox mechanisms in the immune response. J Leukoc Biol, 89(6), 873-91. doi: 10.1189/ jlb.1010550.

[5] Blaise, G. A., Gauvin, D., Gangal, M., \& Authier, S. (2005). Nitric oxide, cell signaling and cell death. Toxicology, 208(2), 177-92. doi. org/10.1016/j.tox.2004.11.032.

[6] Stuehr, D. J. (2004). Enzymes of the L-arginine to nitric oxide pathway. J Nutr, 134 (10 Suppl), 2748S-2751S; discussion 2765S-2767S.

[7] Grimm, E. A., Sikora, A. G., \& Ekmekcioglu, S. (2013). Molecular pathways: inflammation-associated nitric-oxide production as a cancer-supporting redox mechanism and a potential therapeutic target. Clin Cancer Res, 19(20), 5557-5563. doi.org/10.1158/1078-0432.ccr-12-1554.

[8] Rahat, M. A., \& Hemmerlein, B. (2013). Macrophage-tumor cell interactions regulate the function of nitric oxide. Front Physiol, 4, 144 doi: $10.3389 /$ fphys.2013.00144.

[9] Zafirellis, K., Zachaki, A., Agrogiannis, G., \& Gravani, K. (2010). Inducible nitric oxide synthase expression and its prognostic significance in colorectal cancer. APMIS, 118(2), 115-24. doi: 10.1111/j.16000463.2009.02569.x

[10] Gochman, E., Mahajna, J., Shenzer, P., Dahan, A., Blatt, A., Elyakim, R., \& Reznick, A. Z. (2012). The expression of iNOS and nitrotyrosine in colitis and colon cancer in humans. Acta Histochem, 114(8), 827-35. doi: 10.1016/j.acthis.2012.02.004. 